\title{
A PUBLICIDADE COMO FERRAMENTA DE CONSUMO: UMA REFLEXÃO SOBRE AS NOVAS REGRAS DA ANVISA À RESPEITO DOS ALIMENTOS E BEBIDAS QUE CONTÉM INGREDIENTES ALERGÊNICOS
}

\author{
ADVERTISING AS CONSUMER TOOL: A REFLECTION ON THE NEW RULES \\ TO RESPECT ANVISA FOOD AND BEVERAGES CONTAINING INGREDIENTS \\ ALLERGEN
}

${ }^{1}$ Lucimara Deretti

\section{RESUMO}

$\mathrm{O}$ artigo analisa a publicidade como uma ferramenta para o consumo e a influência que exerce sobre a vida das pessoas. O consumidor tem o direito de ser informado das características dos produtos e serviços, visando o cumprimento do princípio da transparência. A publicidade visa a venda dos produtos e serviços, diferente da propaganda que tem objetivo de influenciar ou modificar a opinião alheia, a respeito de determinada ideologia, A publicidade, sem dúvidas tem poder de persuadir o consumidor para que adquira determinado produto ou serviço, e até mesmo criar necessidades, no entanto, essa persuasão também pode ser utilizada para modificar a consciência do consumidor, como por exemplo, no pósconsumo. Além disso, quando se fala especificamente dos alimentos, sabe-se que a publicidade também tem forte influência, pois os alimentos e bebidas não são apenas necessidades para o desenvolvimento, mas influencia o psicológico, econômico e social das pessoas, neste aspecto, surge a necessidade e dever de informação e o princípio da transparência quanto a composição, características, qualidades, quantidades, preço, etc., para todos os alimentos, mas, em especial, neste estudo, para os alimentos que contém ingredientes alergênicos, viabilizando o dever de transparência para essas pessoas que possuem alergias alimentares. Neste aspecto se faz importante refletir sobre a publicidade, sua influência, assim como, sobre a rotulagem desses alimentos que passa a ser obrigatória, a partir das novas regras de Anvisa, possuindo, os fornecedores, um ano para se adaptarem a este novo dever de informação.

Palavras-chave: Consumo, Publicidade, Propaganda, Ingredientes alergênicos, Anvisa

\footnotetext{
${ }^{1}$ Mestranda em Direito pela Pontifícia Universidade Católica do Paraná - PUC, Paraná (Brasil). Professora de Direito pelo Centro Universitário - Católica de Santa Catarina - Jaraguá do Sul - UNERJ, Santa Catarina (Brasil). E-mail: luderetti@gmail.com
} 


\begin{abstract}
The article looks at advertising as a tool for consumption and the influence it has on people's lives. You have the right to be informed of the characteristics of products and services in order to meet the principle of transparency. Advertising aimed at the sale of goods and services, different from the propaganda that has aimed to influence or modify other people's opinion, regarding particular ideology, Advertising, undoubtedly has the power to persuade consumers to buy a product or service, and even design requirements, however, this inducement can also be used to modify the consumer awareness, such as post-consumer. Also, when speaking specifically of foods, it is known that advertising also has strong influence because the food and drinks are not just requirements for development, but influences the psychological, economic and social people, in this aspect, the surge need and duty to inform and the principle of transparency regarding the composition, characteristics, quality, quantity, price, etc., for all foods, but especially in this study for foods containing allergenic ingredients, allowing the duty to transparency for those people who have food allergies. In this respect it is important to reflect on advertising, their influence, as well as on the labeling of such foods that will be mandatory from the new rules of Anvisa, possessing, vendors, a year to adapt to this new duty information.
\end{abstract}

Keywords: Consumption, Publicity, Advertising, Allergenic ingredients, Anvisa 


\section{INTRODUÇÃO}

O presente artigo científico pretende analisar a influência que publicidade exerce sobre os consumidores, o constante incentivo à aquisição de produtos e serviços tornou-se uma característica da sociedade capitalista em que vivemos. Assim, pretende-se fazer uma reflexão sobre o poder de persuasão que a publicidade exerce, compreendendo como o discurso publicitário se constitui para interferir diretamente na tomada de decisão dos consumidores, em vista disso, tem-se o dever de informar do fornecedor sobre todas as características dos produtos e serviços e o princípio da transparência.

Aliados a isso, as novas regras da Anvisa vem efetivar esse dever de informar e o princípio da transparência, pois, torna-se obrigatória a informação dos ingredientes alergênicos nos alimentos e bebidas, sendo que, dentro de um ano, os fornecedores terão que se adaptar a esta regra. Neste sentido, a publicidade e a rotulagem destes alimentos sofrerão mudanças significativas, que merecem estudo.

Para tanto, num primeiro momento, busca-se analisar o conceito de publicidade e propaganda, apesar de muitas vezes essas palavras terem como sinônimos, não significam a mesma coisa, pois seus objetivos são diferentes. Enquanto a propaganda tem objetivo de influenciar ou modificar a opinião alheia, a respeito de determinada ideologia, a publicidade tem objetivo, tem objetivo bem diferente, que é vender, ou seja, captar a atenção do público para o consumo de determinados produtos e serviços.

Neste aspecto, pode-se observar desde já, que a publicidade tem o poder de persuadir o consumidor, chamando a atenção, e até mesmo criando necessidades, pois, o que se observa na atual sociedade globalizada em que vivemos, é que as pessoas têm a necessidade incontrolável de adquirir os produtos ofertados e, principalmente, as novidades, lançamentos, produtos em oferta e promoção. Porém, é neste intenso desejo de consumir, que surge a eficiente publicidade persuasiva, despertando nos consumidores o desejo de adquirir produtos.

A Publicidade teve função primária a informação, no entanto, foi modificando-se ao longo de tempo e subordinada pela nova função persuasiva, diante desta nova função os consumidores perdem sua liberdade, são manipulados pelos anúncios publicitários, e, em meio a tudo isso, é que surge o Código de Defesa do Consumidor, trazendo vários dispositivos legais, coibindo a publicidade abusiva, enganosa por ação ou omissão, assim como a publicidade invisível, entras formas de manipular o consumidor, prevendo, inclusive, punições, na busca para manter o equilíbrio das relações de consumo. 
Desta forma, o Código de Defesa do Consumidor, traz em suas regras o dever de informar que o fornecedor possui e o princípio da transparência, que equivale ao fornecedor informar de forma precisa, clara e correta sobre o produto ou serviço a ser negociado, prestandose a lealdade, boa-fé, confiança e respeito nas relações entre fornecedor e consumidor, desde a fase pré-contratual.

Destarte, o direito à informação clara, precisa e adequada, que vem expresso no artigo $6^{\circ}$, III, do CDC, decorre do princípio da transparência, no caput do artigo $4^{\circ}$. Assim, é obrigação do fornecedor informar os consumidores, de maneira clara, precisa e adequada, quanto os produtos e serviços que põe a venda, sobre a correta composição, quantidade, qualidade, características, preço, etc.

Em vista disto, observa-se que a publicidade não precisa apenas ser utilizada sob ótica da massificação da produção e do consumo, a publicidade, por ser um instrumento para atingir esse direito de informação e o princípio da transparência abordado acima, assim como, pode ser utilizado para efetivar as novas regras da Anvisa sobre alimentos e bebidas que contém ingrediente alergênicos. O regulamento da Anvisa obriga o fornecedor, no prazo de um ano, a se adequar as novas regras, devendo informar nos rótulos de seus produtos a existência de 17 (dezessete) alimentos que podem causar alergias alimentares.

Para o cumprimento deste novo regulamento observa-se presente o dever de informar e o princípio da transparência previstos do Código de Defesa do Consumidor, aonde a publicidade e a rotulagem desses alimentos e bebidas terão que se adaptar, assim como, a publicidade, neste aspecto pode contribuir para a efetivação do princípio da transparência, e não apenas para a massificação da venda e do consumo.

Desta forma, tem-se como objetivo, a partir dos estudos acima identificados, verificar a importância da publicidade no dia a dia do consumidor, como influencia e como pode interferir na vida do consumidor que possui alergias alimentares a partir das novas regras da Anvisa. Para tanto, utiliza-se o método hipotético dedutivo para desenvolver o presente estudo, assim como, importante destacar também, que a pesquisa será efetuada por meio da análise de legislação, pesquisa jurisprudencial e doutrinária em livros e periódicos, impressos e em meio eletrônico, sites informativos e governamentais.

Portanto, a publicidade, influencia os consumidores na hora de decidir sobre determinado produto ou serviço, mas, pode se transforma num instrumento de efetivação do princípio da transparência e do dever de informar do fornecedor, tendo em vista as novas regras da Anvisa sobre ingredientes alergênicos nos alimentos e bebidas, mostrando-se assim, a importância do tema central da pesquisa, pois, inserido no contexto atual. 


\section{PUBLICIDADE E PROPAGANDA}

Os termos publicidade e propaganda muitas vezes são utilizados como sinônimos, no entanto, possuem conceituação distinta, por conta disto, se faz necessário, conceituar-se e estabelecer-se historicamente.

Até o advento e consolidação do direito do consumidor, a publicidade não gerava consequências jurídicas nem para quem utilizasse nem para quem abusasse, era entendida como consequência a ser suportada pela sociedade em razão das atividades econômicas, tanto que, no século XIX a publicidade visava apenas informar os consumidores, pois a decisão concentravase na maioria das vezes pela confiança que o adquirente depositava no fornecedor. No entanto, quando apareceram as primeiras formas de monopólio a publicidade ganha função de persuasão destinada a convencer os consumidores. Com isso, a publicidade não é mais tida apenas para informar o público, mas sim, orientar o consumo, estimular as necessidades e ampliar a demanda (OLIVEIRA, MARAN, 2004, p. 133).

Observa-se então, que devido o desenvolvimento das atividades econômicas e o crescente mercado capitalista nas sociedades de consumo, havia necessidade de coibir a prática abusiva de produtores e fornecedores, surge assim, o Código de Defesa ao Consumidor, que inclui um Capítulo que trata exclusivamente das práticas comerciais; oferta, publicidade, práticas abusivas, cobrança de dívidas e banco de dados e cadastros de consumidores (EFING, 2011, p. 205-206).

Não há sociedade de consumo sem publicidade, e, por conta de sua importância no mercado, existia a necessidade do fenômeno publicitário, ser regrado pelo Direito, e claro, pela perspectiva da proteção ao consumidor, já que, este é ente vulnerável da relação jurídica de consumo (GRINOVER et al, 200, p. 263).

Cabe destacar o que dispõe o artigo 30 e o artigo 36 do CDC:

\footnotetext{
Art. 30. Toda informação ou publicidade, suficientemente precisa, veiculada por qualquer forma ou meio de comunicação com relação a produtos e serviços oferecidos ou apresentados, obriga o fornecedor que a fizer veicular ou dela se utilizar e integra o contrato que vier a ser celebrado.

Art. 36. A publicidade deve ser veiculada de tal forma que o consumidor, fácil e imediatamente, a identifique como tal.

Parágrafo único. O fornecedor, na publicidade de seus produtos ou serviços, manterá, em seu poder, para informação dos legítimos interessados, os dados fáticos, técnicos e científicos que dão sustentação à mensagem.
} 
Conforme expõe Antônio Carlos Efing (2011, p. 206) a palavra oferta, é utilizada pelo legislador no sentido de marketing, designando todos os métodos e técnicas que aproxima o consumidor dos produtos e serviços. Já a publicidade é sinônimo de mensagem publicitária, ou seja, um conjunto de comunicações controladas, identificáveis e persuasivas, transmitidas para criar demanda de produtos e contribuir para boa imagem da empresa (propaganda institucional).

E continua, Antônio Carlos Efing (2011, p. 206) assinalando quais são os princípios adotados pelo CDC quanto a publicidade: princípio da identificação da publicidade, da vinculação contratual da publicidade, da veracidade, da não abusividade da publicidade, do ônus da prova do anunciante, da correção do desvio publicitário - contrapropaganda, da regulamentação penal da publicidade.

Quanto ao artigo 36, a ideia básica é proteger o consumidor, dando garantia e o direito de saber que aqueles dados e informações transmitidos tem uma finalidade específica de promover a venda de um produto ou serviço. Desta forma, visualiza-se que o princípio da identificação obrigatória da mensagem como publicitária, tem sua origem justamente no pensamento de que é necessário tornar o consumidor consciente de que ele é destinatário de uma mensagem patrocinada por um fornecedor, que por sua vez, tem o objetivo de vender algum produto e ou serviço (MARQUES, BENJAMIN, MIRAGEM, 2010, p. 728).

Com isso, para melhor compreender o tema, tem-se que o vocábulo publicidade deriva de público, do latim publicus, e expressa o ato de tornar público. Já, propaganda deriva do latim propagare que quer dizer; reproduzir por meio de mergulhia. Ou seja, enterrar o rebento de uma planta ao solo, o que, em outras palavras, quer dizer enterrar, mergulhar, plantar; isto é, a propagação de princípios, teorias ou doutrinas (OLIVEIRA, MARAN, 2004, p. 134).

A propaganda tem objetivo de influenciar ou modificar a opinião alheia, a respeito de determinada ideologia, enquanto a publicidade tem objetivo de captar a atenção do público para o consumo de determinados bens ou utilização de determinados serviços. Portanto, os termos publicidade e propaganda, apesar de muitas vezes terem como sinônimos, não significam a mesma coisa, pois seus objetivos são diferentes. A propaganda visa influenciar ou modificar a opinião alheia, a publicidade visa captar a atenção do público para o consumo de determinados bens ou serviços (OLIVEIRA, MARAN, 2004, p. 133).

Para Ada Pellegrini Grinover et all (2001, p. 270), não se confundem publicidade e propaganda, embora no dia-a-dia do mercado, os dois termos sejam utilizados como sinônimos. A publicidade tem um objetivo comercial, enquanto a propaganda tem um fim 
ideológico, religioso, filosófico, político, econômico ou social. A publicidade, além de paga, identifica seu patrocinador, o que nem sempre, ocorre com a propaganda.

Para Mara Suely Oliveira e Silvia Maran (2004, p. 136-137) a publicidade tem como mensagem dirigida ao público, a captação do mesmo com finalidade estimular a demanda de produtos e serviços, esta pode se dar, das mais variadas formas, podendo ser o cartaz afixado em locais públicos até o anúncio divulgado nos meios de comunicação sublinhando as qualidades de certos produtos. Enquanto a propaganda é toda forma de comunicação dirigida ao público que tenha por finalidade a propagação de ideias relacionadas à filosofia, à economia, à politica, à religião, ou à arte, sem objetivo comercial.

Para Sant'Anna (2002, p. 75-76) embora utilizados como sinônimos, publicidade e propaganda não significam rigorosamente a mesma coisa, a palavra publicidade significa, genericamente, divulgar, tornar público, já a propaganda compreende a ideia de implantar, incluir uma ideia ou crença na mente alheia. Desta forma, a publicidade é uma técnica de comunicação de massa, servindo para fornecer informações, desenvolver atitudes, provocar ações e vender produtos ou serviços.

Portanto, diante dos conceitos trazidos entende-se que publicidade e propaganda são termos que se distanciam, enquanto a publicidade é forma de comunicação e informação, mas que é difundida com o objetivo direto ou indireto, para que o consumidor adquira um produto ou serviço, a propaganda tem cunho de propagar a difusão de ideias, seja a sistema ideológico de cunho político, social, religioso, econômico, governamental e outros.

A diferença essencial entre os termos aqui estudados, reside na finalidade de cada uma. A publicidade é forma clássica de tornar conhecido um serviço, produto ou uma empresa, incentivando o interesse do consumidor pela coisa anunciada, assim como, também, criar prestígio ao nome, a marca anunciada e etc., o que diferencia do escopo da propaganda.

Ademais disso, a publicidade também pode ser tida de duas formas; institucional ou promocional. Entende-se como institucional aquela que se destina a institucionalizar a marca, ou seja, quem não tem a preocupação com a venda do produto em si, porque o que se anuncia é a empresa. A publicidade promocional tem como objetivo promover a venda de produtos e serviços, ou seja, acelerar a demanda (OLIVEIRA, MARAN, 2004, p. 139).

É fato que a publicidade tem como objetivo primário promover a venda de um produto ou serviço. No entanto, existe também uma função que fica em segundo plano, que é formar a identidade da empresa, enaltecer o conceito do fornecedor, criar e fixar hábitos de consumo, entre outras. Por conta disto, Mara Suely Oliveira e Silvia Maran (2004, p. 139) destacam que 
a publicidade é o instrumento do marketing que visa tornar o produto conhecido, promovendo a compra. Mas, o marketing, não está restrito à publicidade. Ele vai, além da publicidade, compreendendo outros mecanismos de incentivos às vendas, como; cupons, selos, ofertas, promoções, liquidações, prêmios, produtos e serviços grátis, marcas, embalagens, entre outros. O marketing, portanto, é um conjunto de atividades que pode ir desde a concepção, produção, promoção e distribuição.

O artigo 30 citado acima, também quer informar que, quando a publicidade for suficiente e precisa, vincula o fornecedor e equivale à oferta, neste sentido, Antônio Carlos Efing (2011, p. 208-209), esclarece os fundamentos que norteiam a publicidade:

\begin{abstract}
Vale frisar que há distinção entre publicidade e informação, sendo a primeira dependente da segunda (...). A publicidade foi criada primeiramente para informar e alertar o consumidor sobre a qualidade de produtos e serviços por ele adquiridos. Porém, o consumidor em massa e grande competitividade do mercado tornaram a publicidade um meio para ludibriar o consumidor e persuadi-lo a obter bens dos quais não necessita ou cujas virtudes são meramente ilusórias. Essa nova realidade trouxe a necessidade de uma proteção urgente do consumidor, já que o Código Brasileiro de Autorregulamentação Publicitária e outras normatizações pioneiras tinham por escopo estabelecer regras éticas para a atividade publicitária e não propriamente, amparar o consumidor.
\end{abstract}

Ademais disso, também é preciso constar deste estudo, que o Código de Defesa do Consumidor, em seu artigo 37 proibiu a publicidade enganosa ou abusiva. Enganosa é a mensagem publicitária total ou parcialmente falsa, capaz de levar o consumidor a adquirir um produto ou serviço indesejado. A falsidade está ligada ao erro, numa relação de causalidade. Mas, não é necessário que se configure estre erro de fato, basta que exista possibilidade de ser o consumidor induzido a erro (EFING, 2011 p. 211-212).

Diante disto, conforme Antônio Carlos Efing e Maristela Denise Marques de Souza (2014, p. 76) a publicidade é um meio de comunicação em massa da sociedade contemporânea e exerce o poder de envolvimento das massas, pela transmissão de signos, símbolos, imagens e representações do cotidiano, promovendo normas de consumo, influenciando um número crescente de comportamentos individuais e coletivos.

A partir disto, tendo por base que a publicidade é um sistema de comunicação, que os fornecedores utilizam, junto ao seu público-alvo, para divulgar as características e qualidades inerentes ao produto ou serviço com o objetivo de vendê-los, passa-se a observar qual é a influência da publicidade nas decisões dos consumidores, em especial, como a publicidade age na tomada de decisão do consumidor e como a publicidade pode influenciar no dia a dia de cada um de nós. 


\subsection{A influência da publicidade nas decisões de consumo}

Vivemos hoje em uma sociedade de consumo exacerbado de bens, produtos e serviços, Jean Baudrillard chama essa sociedade de Sociedade de Consumo, em sua obra que leva esse nome, e aborda a questão da relação do homem com objetos e o consumo do mesmo. Desta forma, para Baudrillard (2009, p. 15) o consumo está na busca pela felicidade, há consumidores dispostos a consumirem por satisfação, e afirma que existe uma espécie de evidência fantástica do consumo e da abundância, criada pela multiplicação dos objetos, serviços, bens materiais, originando uma mutação fundamental na ecologia espécie humana.

Segundo Baudrillard (2009, p. 38) há um aumento significativo no surgimento de bens, produtos e serviços, a Sociedade de Consumo vive em uma sociedade que admira o novo, favorecendo o surgimento de novos objetos em uma velocidade impressionante, desta forma, se vivemos numa Sociedade de Consumo vivemos também em uma "sociedade de desperdício", pois, sempre buscamos uma "necessidade" de obter algo novo:

Todas as sociedades desperdiçaram, dilapidaram, gastaram e consumiram sempre além do estrito necessário, pela simples razão de que é no consumo do excedente e do supérfluo que tanto o indivíduo como a sociedade, se sente não só existir, mas viver. (BAUDRILLARD, 2009, p.38).

Em, outras palavras, pode-se afirmar que, a Sociedade de Consumo atual, tem o prazer na abastança e na ostentação. É certo que consumir é ato inerente do ser humano, desde os primórdios o consumo tornou-se a base para as atividades humanas e seu desenvolvimento, no entanto, o mercado invadiu todas as atividades sociais, e o indivíduo está sempre buscando a satisfação por necessidades exarcebadas.

E em meio a essa Sociedade de Consumo, o Código de Defesa ao Consumidor vem para tutelar os direitos do consumidor, protegendo-o, o que é na verdade um grande desafio, a Constituição Federal do Brasil de 1988 garante no artigo $5^{\circ}$, que trata dos direitos e garantias fundamentais individuais e coletivos, a defesa e a proteção dos consumidores nas relações de consumo (inciso XXXII), reconhecendo a vulnerabilidade do consumidor e especial proteção. Essa garantia foi reforçada pelo artigo 48 do Ato das Disposições Constitucionais Transitórias, que determinou prazo de cento e vinte dias para a elaboração de lei específica, surge então, o Código de Defesa do Consumidor.

Por outro lado, também há garantia constitucional da livre iniciativa, artigo $1^{\circ}$, inciso IV da Constituição Federal de 1988, assim, a publicidade como atividade econômica, que 
possui objetivos profissionais ou de campanha publicitária, patrocinada por fornecedor que quer vender, encontra fundamento.

No entanto, é preciso destacar como fazem Antônio Carlos Efing e Maristela Denise Marques de Souza (2014, p. 80) que mesmo havendo garantia constitucional da liberdade de expressão ou livre iniciativa previsto na Constituição Federal, tais fundamentos de defesa encontram obstáculo maior em relação a outros direitos e garantias fundamentais, a publicidade e mesmo a informação que incite o consumo inadequado para a saúde física e mental ou que afronta o meio ambiente sustentável e a dignidade da pessoa humana, não pode ser permitida.

Existem vários dispositivos constitucionais que corroboram para a defesa e proteção do consumidor, no entanto, não é intensão esgotar o tema aqui, mas sim, apenas referencia-lo, e observar que, consumidores, de uma fora geral, estão sempre em busca da felicidade, sabedores disto, os fornecedores utilizam a publicidade para seduzir seus alvos.

A publicidade é meio de comunicação em massa que tem objetivo de vender seu produto ou serviço. A ideia assim, da publicidade, é chamar a atenção do consumidor por meio de apelos sedutores. A arte da sedução adentra a publicidade como forma de ganho mercadológico e, muitas vezes, interfere nas decisões do consumidor. Quantas vezes nos vimos seduzidos pelas armadilhas da influência que a publicidade exerce sobre nosso inconsciente?

A constante evolução dos meios de comunicação permite que a publicidade percorra de forma ampla e muito rápida, alcançando uma dimensão e atuando muitas vezes, nos costumes e padrões do consumidor. Neste ínterim, Paulo Jorge Scartezzini Guimarães (2001, p. 97-98) destaca que, após a década de 20, com o surgimento do rádio a baixo custo e da televisão na década de 40, a publicidade passou a ser uma parceira do dia-a-dia. Com o avançar dos anos e dos estudos sobre o comportamento do consumidor, passou-se a investigar como e onde o consumidor irá comprar determinada marca. Nesta exploração da mente humana que os publicitários se apoiam e buscam inspirações para seus anúncios.

Paulo Jorge Scartezzini Guimarães (2001, p. 98) ainda vai além, afirmando que os publicitários criam as necessidades e "após manipulam os consumidores em direção ao produto ou serviço que irá supri-las. Criam efetivamente desejos supérfluos, que, logo em seguida, graças às suas técnicas, são transformadas em produtos imprescindíveis".

Observa-se que, para o autor citado, não há dúvidas que a publicidade influência o consumidor, e essa influência é tamanha, que o consumidor adquire produtos ou serviços, tanto por pressões internas, usos e costumes, como por pressões externas, informações 
inadequadas. Isto deforma o contrato de consumo, ele não é mais ato voluntário, e sim, ato condicionado. Para Paulo Jorge Scartezzini Guimarães (2001, p. 98) “estão corretos aqueles que afirmam que, primeiramente, surge o produto ou serviço; depois é que se inventa a necessidade".

Para Antônio Carlos Efing e Maristela Denise Marques de Souza (2014, p. 78) a publicidade é uma prática efetiva que o fornecedor de produtos e serviços possui para escoar sua produção, neste sentido, inquestionável é o poder de persuasão da publicidade no comportamento dos seres humanos. Para isso, o pressuposto da emoção é utilizado, às vezes de forma conscientes e outras, inconscientes. Ainda que a principal função da publicidade seja a de informar, ela pode despertar, por sua técnica de persuasão, no inconsciente o desejo de adquirir os produtos e serviços ofertados. Na sociedade atual, onde impera a concorrência, a publicidade está sendo utilizada como um instrumento de persuasão e manipulação, que objetiva o consumidor a agir de maneira pré-determinada, privando sua liberdade de escolha.

Para Marques, Benjamin e Miragem (2010, p. 252) explicam que, com a entrada em vigor do $\mathrm{CDC}$, várias aspectos da publicidade comercial passaram a ser juridicamente relevantes, entre elas, destaca-se o efeito vinculativo da publicidade, seja contratualmente, como oferta (art. 30), seja como informação obrigatória clara e correta, ou a responsabilização de quem veicula (art. 35) e a responsabilização solidaria de toda a cadeia de fornecedores (art.

18), tem como objetivo, assegurar a transparência nas relação de consumo, pois, ninguém mais duvida da forte influência que a publicidade exerce sobre a população brasileira.

Paulo Jorge Scartezzini Guimarães (2001, p. 100) faz destaque para uma matéria que foi veiculada no Jornal $O$ Globo em 21 de maio de 1995, com o seguinte título: Quando Freud vai às compras. Tal matéria descrevia as estratégias utilizadas para induzir o consumidor a adquirir produtos. Citando os shoppings, estes não possuem relógios ou luz natural, remetendo a beleza e a ambição, as escadas rolantes obrigam o consumidor a circular por todo o andar. Quanto aos supermercados, normalmente os produtos básicos não se encontram logo na entrada, sendo necessário circular por estantes repletas de produtos supérfluos para encontra-los.

Em vista disso, cabe traçar um limite entre o direito e a consequência dos abusos da publicidade, pois, a publicidade é uma ponte entre o fornecedor e consumidor, que traz para o consumidor informações sobre o produto ou serviço colocado no mercado, e não, influencialo no seu comportamento e violar a sua liberdade de escolha (GUIMARÃES, 2001, p. 101).

No entanto, o poder de persuasão da publicidade ainda vai além, pois, é preciso chamar atenção para as mensagens subliminares, ou, como também é chamado; marketing invisível. É fácil observar que sempre tem alguém comentando sobre um produto ou marca. De como 
é satisfatória, as qualidades, características e de como se preocupa com os clientes. Pode parecer apenas a opinião de uma pessoa legal que quer compartilhar o bom produto ou serviço, mas, no entanto, pode ser o marketing invisível, que usa como estratégia "métodos não convencionais" para criar uma consciência de um produto ou serviço.

Rizzato Nunes (2015, p. 515-516) à respeito do tema, faz destaque para os testemunhais como técnicas de apresentação de produtos e serviços. Geralmente se servem do depoimento de pessoas conhecidas do público consumidor (artistas, esportistas, famosos empresários, e outros) ou mesmo técnicos, peritos e consumidores comuns que, para vender, enaltecem as qualidades, virtudes, vantagens da compra. Essa questão que ganha bastante relevo, tanto que, a norma de autorregulamentação reconhece no testemunhal, técnica capaz de conferir maior força de comunicação, persuasão e credibilidade à mensagem publicitária.

Já, em 1890, no livro “As Leis da Imitação”, do psicólogo Jean-Gabriel, o tema foi motivo de estudo, e gerou grande descoberta, que influenciou o marketing da época, demonstrando que nossas escolhas, ao invés de serem tomadas por decisão soberana, são feitas por mimetismo e contágio.

As mensagens subliminares são exemplos de técnicas manipulativas e persuasivas que privam o consumidor de sua liberdade, faz o consumir crer numa necessidade artificial, levando-o a tomar decisões incitados por erro, acreditando, num primeiro momento que está agindo livremente, mas não (EFING, SOUZA, 2014, P. 78).

Neste ponto específico Antônio Carlos Efing e Maristela Denise Marques de Souza (2014, p. 79), explicam essa influência citando Breton, nos seguintes termos:

\begin{abstract}
Essa influência, que dá um falso senso de liberdade aos consumidores, é descrita por Breton (1999, p. 17) de forma sucinta: "ora, a primeira etapa de toda manipulação consiste justamente em fazer o interlocutor crer que é livre". E a publicidade emprega maciçamente essa mensagem, a comunicação é manipulada, persuadindo seu interlocutor, para promover atitudes benéficas para os anunciantes, venda dos produtos e dos serviços. Como corrobora Del Masso (2009, p.45): (...) em segundo plano, a manipulação não permite ao interlocutor qualquer ato de resistência e indagação; daí a necessidade de ser obrigatoriamente camuflada. As possíveis resistências são colocadas e rebatidas pelo próprio manipulador. Mas o mais importante é o que existe por trás da utilidade do produto a ser vendido: a satisfação do desejo do consumidor.
\end{abstract}

Destarte, a publicidade exerce uma ação psicológica decorrente de um processo de persuasão e manipulação que utiliza técnicas para valorizar o produto e destacar suas vantagens e necessidades, seduzindo e envolvendo o consumidor, produzindo o resultado do consumo, o que se percebe, portanto, é que a publicidade molda o consumidor (EFING, SOUZA, 2014, P. 79). 
Portanto, a publicidade não é apenas uma técnica comercial, mas sim, ela incita, sugestiona e muitas vezes torna necessária a compra de determinado produto. Muito disso, devese a produção em massa de um determinado produto, que, consequentemente, conduz ao consumo em massa, recorrendo os fornecedores às técnicas de persuasão psicológica nos mais diversos meios de comunicação na busca de convencer o maior número de consumidores.

Isabella Vieira Machado Henriques (2008, p. 191) traz uma consideração bem pontual, que merece ser citada aqui, a título exemplificativo, para o presente estudo, que é a publicidade que estimula o consumo excessivo de alimentos entre as crianças, essas publicidades dirigidas ao público infantil voltadas à venda de alimentos, acabam por estimular o consumo excessivo, aonde os fabricantes desses produtos podem ser considerados responsáveis pelo aumento da obesidade entre as crianças. Como exemplo, as publicidades de refrigerantes sempre associadas a uma vida feliz e saudável.

Por outro lado, se a publicidade influência o comportamento do consumidor, não se pode descartar a ideia que a publicidade pode ser utilizada de forma positiva. Se ela é capaz de atingir o inconsciente e o consciente do consumidor individual e coletivo, é fato que também pode ser utilizada como instrumento de conscientização, a exemplo, no pós-consumo, das responsabilidades socioambientais, com objetivo de mudanças no comportamento dos consumidores.

Neste aspecto para Efing e Souza (2012, p.90-91) se a publicidade é utilizada para atrair o consumidor a consumir, poderá inserir atributos positivos a produtos e serviços como forma de conscientização coletiva. É fato que a exploração crescente e ilimitada dos recursos naturais no modelo de crescimento neoliberalista, resultou em danos irreversíveis ao meio ambiente, o que culminou na sociedade que temos hoje, desta forma, já que não é possível descartar o consumo da sociedade que está impregnada culturalmente por este, a proposta permissiva da publicidade, mas, que seja utilizada a favor de um consumo consciente em dois aspectos essenciais da sociedade contemporânea: dignidade da existência humana e natureza, certamente é viável, tendo em vista, a proposta de sustentabilidade econômica, social e ambiental como alternativa desejável (e possível), promovendo a inclusão social, o crescimento e desenvolvimento econômico e preservação dos recursos naturais, se fazendo premente e necessária.

A verdade é que a publicidade deixou de ter papel meramente informativo para influenciar na vida do cidadão de maneira tão profunda a ponto de mudar hábitos e ditar-lhe comportamento. Fato este, consequência da cultura de massas em que vivemos, instalada pela exploração dos meios de comunicação. Portanto, o que se revela é que o consumidor é induzido 
a consumir, bombardeado pela publicidade massiva que o cerca em todos os lugares e momentos do seu dia a dia. Como ato autônomo responde a esse estimulo, sem discernir corretamente, agindo pela emoção (ALMEIDA, 2002, p. 111-112)

No entanto, Colin Campbell (2001, p. 58) sustenta que é um mistério o comportamento do consumidor, ou pelo menos, há um mistério que rodeia o comportamento dos consumidores nas sociedade industriais modernas. Não se refere a escolha dos produtos, nem porque alguns grupos apresentam padrões de consumo diferentes, nem se refere a questão sobre quanto de um produto uma pessoa consente em comprar por um dado preço. O mistério é mais fundamental, como uma atividade que envolve uma busca interminável de necessidades; o aspecto mais característico do consumo moderno é essa insaciabilidade.

É conclusivo que a publicidade influencia o modo de vida, o consumidor compra produtos e serviços de forma condiciona, no atual cenário do mundo capitalista, o consumidor é condicionado, na maioria das vezes a adquirir determinado produto ou serviço, seja pela publicidade invisível ou não, no entanto, verifica-se que, se a publicidade influência de tal maneira a persuadir o consumidor, pode também ela ser utilizada a favor da consciência ambiental, mostrando-se como alternativa para conseguirmos alcançar o desenvolvimento econômico sustentável, que, por sinal, também é direito fundamental de todos, tendo em vista o artigo 225 da Constituição Federal.

\subsection{Direito à informação clara e precisa - princípio da transparência}

O dever de informação e o princípio da transparência dão ao consumidor, o direito à informação clara e precisa dos produtos e serviços, consequentemente a falta de informação clara e precisa nos rótulos dos alimentos industrializados oferece riscos à saúde da população, por conta disto, em primeira plano analisa-se dever de informação e o princípio da transparência, para depois, adentrar no tema específico sobre as mudanças que a Anvisa nos trouxe recentemente.

O direito a informação vem garantido na Constituição, como direito fundamental da pessoa humana, no artigo $5^{\circ}$, inciso XIV. No CDC, entre os direitos básicos do consumidor, está a informação, que deve ser adequada e clara sobre os diferentes produtos e serviços, com especificação correta de quantidade, características, composição, qualidade e preço, bem como, sobre os riscos que apresentam, de acordo com a disposição do artigo $6^{\circ}$, inciso III.

Além disso, no artigo 31, tem-se que a apresentação de produtos ou serviços devem assegurar informações corretas, claras, precisas, ostensivas e em língua portuguesa sobre suas 
características, qualidades, quantidade, composição, preço, garantia, prazos de validade e origem, entre outros dados, bem como, sobre os riscos que apresentam à saúde e segurança dos consumidores, sendo vedada, pelo artigo 37, a publicidade enganosa inteira ou parcialmente falsa, ou, mesmo por omissão, capaz de induzir em erro o consumidor.

O CDC tem como princípio básico o reconhecimento da vulnerabilidade do consumidor, no artigo $4^{\circ}$, inciso I e a necessidade do Estado em proteger esses direitos, no artigo $4^{\circ}$, inciso II. Decorrente disto a necessidade de proteção da liberdade do contratante mais fraco, qual seja; o consumidor. Essa liberdade de escolha de contratar, se dá através do dever de informação imposto ao fornecedor, para que o consumidor possa escolher o melhor lhe convier, por exemplo, informação em relação à presença de transgênicos nos alimentos (BENJAMIN, MARQUES, BESSA, 2014, p. 76).

No artigo $4^{\circ}$, inciso III, há exatamente a segurança deste direito básico à informação, realizando a transparência no mercado de consumo, devendo a informação ser clara e adequada, haja vista que, rege o momento pré-contratual, a eventual conclusão do contrato e o próprio contrato. A informação, portanto, é mais do um elemento formal, e sim, afeta a própria essência do negócio, pois a informação integra o conteúdo do contrato, ou, se falha, representa a falha (vício) na qualidade do produto ou serviço. Revelando-se que, o direito à informação assegurado no artigo $6^{\circ}$, III, deve ser cumprido pelo fornecedor, e não fraudada (BENJAMIN, MARQUES, BESSA, 2014, p. 77).

Para Rizzatto Nunes (2015, p. 183) o dever de informar é princípio fundamental do $\mathrm{CDC}$, aparecendo incialmente no inciso III do artigo $6^{\circ}$ do $\mathrm{CDC}$, junto ao princípio da transparência no artigo $4^{\circ}$, caput, traz uma nova formatação de produtos e serviços fornecidos no mercado. O fornecedor está obrigado a prestar todas as informações acerca do produto e do serviço, suas características, qualidade, riscos, preços, etc., de maneira clara e precisa não se admitindo falhas ou omissões. É dever exigido antes mesmo do início de qualquer relação de consumo, a informação é componente necessário do produto e do serviço.

Quanto ao dever de informar, especificamente BENJAMIN, MARQUES e BESSA (2014, p. 263) deixam claro que a informação, no mercado de consumo é oferecida em dois momentos principais, uma informação que precede (publicidade, por exemplo) ou acompanha (embalagem, por exemplo), e outra informação é aquela passada no momento da formalização do ato da contratação. Ambas têm o mesmo objetivo de passar informações adequadas e preparar o consumidor para o ato livre da contratação.

Importante destacar que não é qualquer modalidade informativa que atende os ditames do Código, a informação deve ser correta (verdadeira), clara (de fácil entendimento) 
precisa (sem prolixidade), ostensiva (de fácil percepção) e em língua portuguesa. O consumidor bem informado é apto a encontrar-se e atuar livremente no mercado de consumo, no entanto, essas informações muitas vezes, não estão à sua disposição, por melhor que seja sua escolaridade, ele não tem, por si só, o poder de apreender toda a complexidade do mercado (BENJAMIN, MARQUES e BESSA 2014, p. 266).

Sobre o direito à informação, Marques, Benjamin e Miragem (2010, p. 248) fazem a seguinte afirmação: "Resumindo, como reflexo do princípio da transparência temos o novo dever de informar o consumidor". E ainda dispõe sobre o assunto:

\begin{abstract}
Informar é "dar" forma, é colocar (in) em uma "forma" (in-forma-r), aquilo que um sabe ou deveria saber (o expert) e que o outro (leigo) ainda não sabe (consumidor). A informação é, pois, uma conduta de boa-fé do fornecedor e como direito do consumidor (Art. 6, III) conduz a um dever (anexo de boa-fé) de informar do fornecedor de produtos e serviços. Daí que o dever de informar é um dever de conduta ou de comportamento positivo (...) onde o silêncio é violação do dever ou enganosidade (MARQUES, BENJAMIN E MIRAGEM, 2010, p. 249).
\end{abstract}

Neste aspecto, verifica-se que a transparência, a informação correta, está diretamente ligada à lealdade, ao respeito no tratamento entre parceiros, é a exigência de boa-fé entre fornecedor e consumidor (MARQUES, BENJAMIN E MIRAGEM, 2010, p. 248)

Quanto aos dados integrantes do dever de informar, estes podem ser os mais variados, a depender do produto e serviço, no entanto, o CDC estabelece algumas informações básicas: características, qualidades, quantidade, composição, preço, garantia, prazos de validade, origem e riscos. Essas informações deve estar claras, precisas e ostensivas. Normas especiais podem ampliar essa lista, mas nunca restringi-la (BENJAMIN, MARQUES E BESSA, 2014, p.268). Como é o caso da regulamentação específica de alguns alimentos alérgicos, objeto de estudo deste artigo.

Além disso, Rizzatto Nunes (2015, p. 184), faz importante lembrança sobre a proteção contra a publicidade enganosa ou abusiva, sustentando que este princípio previsto no inciso IV do artigo $6^{\circ}$ nasce como expressão do princípio maior estampado no texto constitucional relativo a publicidade e decorrente de toda lógica do sistema do CDC, haja vista o controle efetivo dos produtos e serviços no que diz respeito à qualidade, adequação e segurança. A informação a respeito das características qualidade, funcionamento, preço, etc., é elemento essencial dos produtos e serviços. Ademais, destaca que produção e publicidade não se confundem, a publicidade representa a "produção" realizada pelo publicitário ou agência, em razão de existir algum produto e serviço que se queira mostrar e/ou vender. A publicidade assim é instrumento de apresentação e/ou venda dessa produção. 
Destaca-se também que não é só a publicidade que pode ser enganosa, pois a embalagem geralmente também é veículo de marketing, e esta não se pode prestar enganosidade também. Deve-se distinguir dois aspectos da embalagem: seu design (tamanho e forma), e sua decoração (palavras e imagens). Esta última de certa maneira, confunde-se com o próprio conceito de rótulo, no entanto, em ambos é possível a manifestação da enganosidade. Desta forma é enganoso sugerir mediante forma especial (design) que o recipiente contem mais produto do que realmente tem. Outro exemplo, também há enganosidade na rotulagem que induz o consumidor a crer que se trata de produto natural, quando, na verdade, é artificial (BENJAMIM, MARQUES, BESSA, 2004, p. 268-269).

No entanto, em meio a tudo isto, cabe também destacar, que a oferta ou veiculação de imagem publicitária é declaração unilateral da vontade que visa um negócio jurídico, se, havendo a manifestação da vontade da outra parte, tem início a formação do contrato. Assim, as informações veiculadas pelo fornecedor obriga no contrato nos termos do que fora proposto o anunciante, por conta disto, a oferta e a publicidade possuem as características de se tornarem irrevogáveis, irretratáveis e irrenunciáveis (EFING, 2011, p. 207).

O CDC ainda determinou que a oferta e a apresentação de produtos ou serviços devem assegurar informações corretas, claras, precisas, ostensivas e em língua portuguesa sobre suas características, qualidades, quantidade, composição, preço, garantia, prazos de validade e origem, entre outros dados, bem como, sobre os riscos que apresentem à saúde e segurança dos consumidores, de acordo com o artigo 31 do referido Código. Verifica-se que a intenção do legislador com este dispositivo, foi garantir ao consumidor o maior número possível de informações sobre o produto ou serviço ofertado para que o consumidor, diante de todos os dados necessários, possa decidir livremente pela aquisição ou não do produto ou serviço (EFING, 2011, p. 207).

Não há um dever legal, imposto ao fornecedor, de anunciar seus produtos e serviços, o que existe é uma obrigação de informar positivamente o consumidor, só que esta incumbência não precisa ser cumprida através de mensagens publicitárias stricto sensu. O Código, portanto, não obriga o fornecedor a anunciar, a publicidade, por este prisma, não é um dever, e sim, um direito, mas, um direito exercitável à conta e risco do anunciante. O legislador não sanciona a carência de publicidade, mas sim, a má ou insuficiente informação (GRINOVER, 2001, p. 263).

Para Rizzatto Nunes (2015, p. 176) o princípio da transparência, exposto no caput do artigo $4^{\circ}$ do CDC, se traduz na obrigação do fornecedor de dar ao consumidor a oportunidade de conhecer os produtos e serviços que soa oferecidos e também, gerará a obrigação de propiciar 
o conhecimento prévio do seu conteúdo. Assim, o princípio da transparência será complementado pelo princípio do dever de informar, previsto no inciso III do artigo $6^{\circ}$ do CDC, e a obrigação de apresentar previamente o conteúdo do contrato, regrado no artigo 46.

BENJAMIN, MARQUES e BESSA (2014, p. 77) fazem referência a recente acórdão do STJ que enfrentou a questão que ficou conhecida como "maquiagem do produtos", destacando justamente o dever de informar sobre redução de quantidade de produto, neste caso, o Procon estadual havia instaurado processo administrativo contra a recorrente prática do aumento disfarçado dos preços, por alterar a quantidade do conteúdo dos refrigerantes de $600 \mathrm{ml}$ para $500 \mathrm{ml}$, sem informar de forma clara e precisa aos consumidores, porquanto a informação foi posta na parte inferior do rótulo e em letras miúdas. A questão foi combatida pelo STJ, haja vista que a informação deficiente frustra as legítimas expectativas do consumidor, maculando a confiança.

Além do dever de informação, o princípio da transparência e boa-fé combate o abuso, quando no artigo $4^{\circ}$, caput, atua como um reflexo da boa-fé exigida dos agentes contratuais, assim como, quando no artigo $6^{\circ}$, inciso IV, proíbe o abuso de direito.

Assim, o se encontra no direito do consumidor, é que este, preocupa-se muito mais, com a fase pré-contratual, afinal, é justamente nela que se constitui a atividade destinada a dar vida ao futuro contrato, o dever de informar é um essencial, para a harmonia e equilíbrio de todas as relações de consumo, por conta disto, é que o fornecedor deve sempre prestar as informações ao consumidor sobre o conteúdo do contrato, dando especial ênfase para possíveis riscos a saúde que aquele produto ou serviço pode causar.

Destarte, importante destacar, e em especial, quando se fala em dever de informar e princípio da transparência para produtos alergênicos, que a questão tornou-se vital, pois a falta delas, pode trazer sérias complicações as pessoas.

Henriques (2008, p. 64-65) traz o princípio da veracidade da mensagem publicitária, aduzindo que este princípio diz respeito à autenticidade da informação publicitária , fundada no princípio da boa-fé e da igualdade, haja vista, ser imprescindível a divulgação de informação verdadeira pelo fornecedor, mesmo porque, o CDC no artigo 37, parágrafo $1^{\circ}$ proíbe toda publicidade enganosa, seja por omissão ou não, artigo 37 , parágrafo $3^{\circ}$. O CDC não permite nem mesmo, uma "meia-verdade", a publicidade deve ser inteiramente verdadeira, senão, será considerada enganosa.

Henriques (2008, p. 65-66) ainda faz constar o princípio da não-abusividade da publicidade, dispondo que esta se assemelha ao da veracidade, pois, também decorrente dos 
princípios da boa-fé e da igualdade entre os sujeitos da relação de consumo, haja vista que a publicidade abusiva atenta contra valores importantes para o consumidor, bem como, abusa da boa-fé da vulnerabilidade na relação de consumo, valendo-se de suas fragilidades diante de alguma oferta publicitária.

Para Oliveira e Maram (2004, p. 145) quando fala-se em princípios do CDC, não se pode deixar de enunciar o princípio da veracidade da publicidade, o CDC consagra este princípio ao proibir e definir a publicidade enganosa (art. 37, parágrafo $1^{\circ}$ ), tratando-se de um dos princípios mais importantes da publicidade e o tem expressão legal mais antiga. Segundo este princípio a publicidade deve ser escorreita e honesta, devendo conter apresentação verdadeira do produto e serviço oferecido, tem como objetivo informar o consumidor, assegurar-lhe escolha livre e consciente, coibindo, portanto, a publicidade enganosa.

Cabe ressaltar que o dever de dar acesso é do anunciante (fornecedor) e não da agência publicitária. Por cautela, deve a mesma, manter a documentação do fornecedor para demonstrar sua não responsabilidade em caso de alegação de publicidade enganosa. Pois, o descumprimento desse principio, além da repercussão cível e administrativa, também é ilícito penal previsto no artigo 69 do CDC (OLIVEIRA, MARAM, 2004, p. 146).

Neste aspecto, o consumidor tem direito à informação clara, ostensiva, precisa e de fácil compreensão a respeito do produto que está adquirindo. Por isso, no rótulo ou na embalagem devem constar a quantidade e as características do produto, composição, qualidade, garantia, origem, preço e eventuais riscos que este ofereça.

Portanto, de acordo com todo o informado acima, verifica-se que no Brasil, o CDC, traz o direito à informação clara e precisa de produtos e serviços, principalmente se houver possíveis riscos a saúde. Quando se fala de alimentos, há uma lei, de n 10.674 de 2003, que regulamenta a obrigatoriedade da informação da presença ou ausência de glúten nos rótulos de alimentos e bebidas, e resoluções da Anvisa também obrigam a declaração da tartrazina e fenilalanina nos rótulos.

Sobre, a rotulagem dos alimentos alergênicos ainda não havia nenhuma medida para que o dever de informação e o princípio da transparência fossem cumpridos, neste sentido, adiante passa-se ao estudo específico dos alimentos alergênicos e o cumprimento dos princípios do Direito do Consumidor. 


\section{NOVAS REGRAS DA ANVISA SOBRE ALIMENTOS E BEBIDAS QUE CONTÉM INGREDIENTES ALERGÊNICOS}

A alimentação influência a vida das pessoas, não só como necessidade para a sobrevivência e desenvolvimento, mas sim, com aspectos social, psicológico e econômico, desta forma, pode-se perceber a dificuldade que é, para as pessoas que possuem alergias alimentares. Com as novas regras recentes da Anvisa, tem-se que a vida dessas pessoas se torna, ao menos, mais informada e transparente.

Neste sentido, diante de informações retiradas do site da Anvisa (2015), a principal preocupação das alergias alimentares é a anafilaxia, que pode levar o indivíduo a óbito se não for tratada imediatamente. O que é ainda mais preocupante, é que pesquisas internacionais indicam que entre 30 a 50\% dos casos de anafilaxia são causadas por alimentos. Em crianças, esses números podem alcançar $80 \%$ dos casos. Além de representar um sério risco à saúde, quem tem alergias alimentares precisa tomar mais cuidados, assim como, também gastam mais com alimentação e saúde, atividades rotineiras acabam se tornando complexas, dificultando o gerenciamento das relações sociais e das atividades de lazer, além de elevar os níveis de estresse e ansiedade.

É também informação do site da Anvisa (2015), que o consumo de pequenas quantidades do alimento alergênico pode ser suficiente para provocar reações clínicas severas, por conta disto, é necessário leitura cuidadosa dos rótulos dos alimentos, para não incorrer em uma alergia alimentar. Verifica-se, portanto, que o acesso a informações corretas e claras é essencial para o gerenciamento do risco de alergias alimentares. Caso o alimento alergênico seja consumido por pessoas sensíveis, pode ser necessária a intervenção médica para reverter os efeitos clínicos agudos e evitar reações anafiláticas.

$\mathrm{O}$ acesso a informações adequadas sobre a presença dos constituintes alergênicos nos alimentos é essencial para proteger a saúde de indivíduos com alergias alimentares. Para tanto, observa-se a importância do princípio da transparência e do dever de informar do fornecedor, haja vista que, a rotulagem, neste caso, é o principal meio de comunicação entre o fornecedor e o consumidor sobre a presença, ou não, de alergênicos.

De acordo com o site da Anvisa (2015), a iniciativa para constar nos rótulos dos produtos industrializados a presença de alimentos alergênicos foi devido a constatação de diversos problemas na transmissão de informações nos rótulos, entre eles; o emprego de terminologias técnicas ou científicas na lista de ingredientes (ex. caseína, que é uma proteína do leite); a declaração de muitos ingredientes por meio de termos genéricos que não identificam 
sua origem (ex. óleos vegetais, amido); a ausência de declaração de alguns constituintes de ingredientes compostos e dos coadjuvantes de tecnologia na lista de ingredientes; a legibilidade inadequada das informações relativas à composição dos alimentos.

Para que os consumidores possam realmente exercer o direito a informação e o princípio da transparência, a rotulagem obrigatória dos principais alimentos que causam alergias alimentares foram estabelecidos pela RDC n. 26/2015, que foi publicada no Diário Oficial da União n. 125, de 03/07/2015, o objetivo desta norma é garantir que os consumidores tenham acesso a informações corretas, compreensíveis e visíveis sobre a presença dos principais alimentos que causam alergias alimentares na rotulagem dos alimentos embalados.

Para entender melhor compreender como isso tudo aconteceu, de acordo com o site do Idec, foi realizada na Anvisa (Agência Nacional de Vigilância Sanitária), nos dias 15 e 16 de abril de 2015, reunião para discutir uma proposta de regulamentação da rotulagem de alimentos alergênicos. A reunião foi motivada pela DICOL (Diretoria Colegiada) da Agência que decidiu pela aprovação de uma regulamentação, devido ao grande número de ações civis públicas e da ação de consumidores que se manifestaram sobre o tema. Houve até mesmo uma campanha com a seguinte intitulação Põe no Rótulo.

De acordo com informações do site do IDEC (2015), a campanha Poe no Rótulo nasceu de um grupo de 600 mães do Brasil todo que tinham em comum a alergia alimentar de seus filhos. Eles se mobilizam por informações claras nos rótulos dos alimentos. Existe, nas indústrias, uma prática comum de compartilhamento de maquinário para produção de vários produtos e alimentos. Depois de fabricados, esses alimentos são comercializados com informações incompletas nos rótulos. Um alérgico alimentar corre risco de morte dependendo do seu grau de sensibilidade, por isso a necessidade de saber exatamente o que está consumindo. A campanha defende que um rótulo claro e correto é bom pra todos, não só para o alérgico alimentar, mas para os diabéticos, os celíacos, as gestantes, pessoas com pressão e colesterol altos.

Desta forma, a resolução aprovada para dar o direito a informação aos consumidores, sobre a presença ou não de produtos alergênicos nos alimentos e bebidas, de acordo com o site da Anvisa, abrange dezessete alimentos, quais sejam: trigo (centeio, cevada, aveia e suas estirpes hibridizadas); crustáceos; ovos; peixes; amendoim; soja; leite de todos os mamíferos; amêndoa; avelã; castanha de caju; castanha do Pará; macadâmia; nozes; pecã; pistaches; pinoli; castanhas, além de látex natural. 
Segundo o regulamento, e informações obtidas através do próprio site da Anvisa (2015), os derivados dos produtos acima informados, devem trazer a informação: “Alérgicos: contém (nomes comuns dos alimentos que causam alergias alimentares)", "Alérgicos: contém derivados de (nomes comuns dos alimentos que causam alergias alimentares)" ou "Alérgicos: contém (nomes comuns dos alimentos que causam alergias alimentares) e derivados”. Em casos onde não é possível garantir a ausência de contaminação cruzada dos alimentos (que é a presença de qualquer alergênico alimentar não adicionado intencionalmente, como no caso de produção ou manipulação), o rótulo deverá constar a declaração “Alérgicos: pode conter (nomes comuns dos alimentos que causam alergias alimentares)".

Além disso, de acordo com a citada resolução, essas advertências, deverão estar agrupadas imediatamente após ou logo abaixo da lista de ingredientes e com caracteres legíveis, em caixa alta, negrito e cor contrastante com o fundo do rótulo. Para tanto, os fabricantes terão 12 (doze) meses para adequar as embalagens, e os produtos fabricados até o final do prazo de adequação poderão ser comercializados até o fim de seu prazo de validade.

Diante desta nova resolução da Anvisa, o que se observa é o direito a informação clara e precisa, assim como, o princípio da transparência, citados alhures, acontecendo, haja vista que somente assim, o consumidor poderá escolher, poderá agir livremente dentro que melhor lhe convir, haja vista que, a publicidade da rotulagem desses alimentos deverá ser clara, precisa e ostensiva, beneficiando o consumidor.

\subsection{A questão da rotulagem e da publicidade dos alimentos alergênicos}

A publicidade exerce uma grande influência na vida dos consumidores, conforme já ficou destacado acima, e quando essa publicidade é referente alimentos, não deixa de ser diferente. Diante da conceituação acima do dever informar e do princípio da transparência, que a informação repassada ao consumidor deve ser clara precisa e conter os elementos necessários para o consumidor escolher dentro do seu livre consentimento, a regulamentação sobre alimentos alergênicos vai ao encontro desse dever de informar e do princípio da transparência.

Para Benjamin, Marques e Bessa (2014, p. 270) "não há sociedade de consumo sem publicidade. Como decorrência de sua importância no mercado, surge a necessidade de que o fenômeno publicitário seja regrado elo direito, notadamente pela perspectiva da proteção do consumidor". 
Com as novas regras da Anvisa sobre os alimentos e bebidas que possuem ingrediente alergênicos, os fornecedores terão que se adequar, dentro do prazo de um ano, a publicidade e informação da rotulagem desses produtos, que acima foram destacados, com isso, os consumidores ganham informação. A publicidade então, pode ajudar os consumidores no direito a informação, basta que esta informação venha para beneficiar o consumidor, ou seja, que venha de forma clara, precisa e transparente.

Do mesmo modo, como aconteceu com os produtos transgênicos, que trouxe liberdade de escolha para os consumidores, pois, o Decreto 4.680, de 24 de abril de 2003 que substituiu o Decreto 3.871/2001, regulamentando a rotulagem dos alimentos transgênicos, tornou assim, obrigatória a rotulagem destes produtos, para que o consumidor saiba que o mesmo contém transgênicos e possa decidir se quer ou não adquiri-lo. Os fornecedores da área da alimentação então, devem identificar com o símbolo composto por uma letra T, preta, sobre um triângulo amarelo os produtos que contém mais de $1 \%$ de matéria-prima transgênicas.

Infelizmente, a realidade da rotulagem, é outra, além de muitos fornecedores nem mesmo respeitar essa rotulagem, o Brasil ainda anda na contra mão, havendo projeto de lei, já aprovado na Câmara, que visa acabar com esta rotulagem dos transgênicos.

É importante destacar que a própria publicidade que informa se tal produto contém transgênico ou não, é falha, haja vista que, muitos consumidores nem mesmo conhecem este símbolo, mas, retirar a pouca informação que há nesses alimentos, é rasgar o dever de informação que o fornecedor deve ao consumidor e o princípio da transparência.

Heline Sivine Ferreira (2008, p. 133) faz importante consideração à respeito dos organismos transgênicos, e o risco associado a estes de causar danos à saúde dos seres vivos. É através do DNA recombinado que se insere no genoma do organismo receptor genes capazes de expressar determinadas proteínas com funções específicas, a exemplo da toxina $\mathrm{Bt}$, que se propõe a tornar a cultivar transgênica resistente ao ataque de insetos. Mesmo que a toxicidade seja analisada antes da liberação para uso comercial, não se pode descartar a hipótese que essas substâncias possam ser tóxicas e prejudiciais à saúde dos seres vivos.

No entanto, o que se quer, é mostrar que o consumidor tem direito da informação, e é ele que faz a escolha, se quer comprar determinado produto ou não, que contenha alimento transgênico, ou seja, a publicidade neste caso pode viabilizar o princípio da transparência, ajudando o consumidor. $\mathrm{O}$ mesmo acontece com os alimentos alergênicos, a publicidade, que tem o objetivo da venda, também pode conter a informação das características, qualidades, quantidade e ingredientes dos alimentos e bebidas, sendo fundamental para a garantia do princípio da transparência. 
Assim, fazendo comparação com a questão dos alimentos transgênicos, Vieira e Vieira Junior (2008, p. 125) destacam que a questão da rotulagem ou identificação dos transgênicos é uma forma de exigir o cumprimento do Código de Defesa do Consumidor fazendo prevalecer a vontade do cidadão no processo decisório de consumir com base em informações seguras e precisas.

Neste sentido, é Marques, Benjamin e Miragem (2010, p. 247) afirmando que informar ao consumidor da transgenia existente é preservar a liberdade do consumidor e a informação constante no artigo $5^{\circ}$, caput e no inciso XIV da $\mathrm{CF} / 98$, assim como, é preservar o direito de escolha do consumidor previsto no artigo $6^{\circ}$, inciso II do CDC, esse diálogo das fontes extrai um direito fundamental à informação, sobre gêneros alimentícios, derivado do direito básico à autodeterminação alimentar dos consumidores brasileiros.

Assim, também é a liberdade de escolha dos consumidores quanto aos alimentos alergênicos, aonde a publicidade, neste caso, pode ajudar e contribuir, para as pessoas que possuem alergias alimentares, sendo de fácil identificação as embalagens e rotulagens destes alimentos, é neste sentido que a publicidade pode viabilizar esta contribuição.

Célia Craveiro e Sílvia Cunha (2007, p. 58-59) ao discorrerem sobre o assunto abordam a questão da publicidade alimentar, que tem como principal, objetivo, a promoção de produtos alimentares visando a compra e consumo destes. A indústria alimentar, por utilizar vários canais de difusão dos seus produtos (televisão, rádio, jornais, revistas, entre outros) é vista como um grande "cliente" publicitário. Um consumidor informado, consciente e clarificado pode ser a peça chave para poder efetuar escolhas corretas, mesmo sendo alvo diário de publicidades agressivas.

Com o novo perfil do consumidor que se delineia, ou seja, cada vez mais consciente e interessado por informações, o marketing tem explorado ao máximo os recursos da embalagem e rotulagem dos alimentos, destacando sobretudo os "possíveis" atributos benéficos à saúde, através da propaganda nutricional. Neste sentido, o consumidor, deve adotar uma postura crítica, usando seu poder de compra para impugnar ou prestigiar seus fornecedores. $\mathrm{E}$ no processo de conscientização e educação da população, os profissionais da saúde e órgãos de defesa do consumidor possuem papel preponderante (ISHIMOTO, NACIF, 2011, p. 33).

Neste cenário, aonde o consumidor é o agente receptivo das informações alimentares diárias, Anderson Cleber Rodrigues e Isabel Cristina Rodrigues (2002, p. 01-02), fazem uma ponderação importante, pois os fornecedores, devem se concentrar na tarefa de oferecer estas informações de forma rápida e acessível. A comunicação é meio poderoso contrato entre fornecedor e consumidor. Quando o produto a ser divulgado contempla atributos específicos, 
é preciso que se tenha real noção do grau de conhecimento do receptor, para melhor lhe atender, com formas estratégicas de comunicação da publicidade. Portanto, o que ser, é mostrar que a publicidade pode servir como importante ferramenta para efetivar o princípio da transparência e o dever de informar do fornecedor, se, exerce forte influência sobre as pessoas, também pode servir de veículo condutor para boas ações, neste sentido, veículo de informação.

\section{CONSIDERAÇÕES FINAIS}

Foi possível perceber que a publicidade é, muitas vezes, ferramenta de consumo, podendo determinar as formas de consumo e até mesmo criar necessidades, nesta perspectiva, refletir sobre as modificações que se fazem necessárias na rotulagem dos alimentos alergênicos se traduz como importante e atual, haja vista, a aplicabilidade do princípio da transparência e o dever de informar do fornecedor sobre todas as características, qualidades, quantidades, substâncias, etc., que contém esses produtos.

A publicidade e a propaganda são termos comumente confundidos, no entanto, é preciso estabelecer que a publicidade não se confunde com a propaganda, embora facilmente se observa os dois termos sendo utilizados como sinônimos. A publicidade tem objetivo comercial, enquanto a propaganda tem fim ideológico, religioso, filosófico, político, econômico ou social.

A publicidade influência o consumidor, tem um poder de persuasão capaz de lhe retirar a liberdade de escolha, muito disto, é consequência da sociedade capitalista em que vivemos, aonde a publicidade é utilizada para vender, persuadir e criar necessidades. No entanto, esta publicidade também pode ser utilizada para informar, como por exemplo, a informação necessária aos consumidores, sobre os ingredientes alergênicos presentes nos alimentos e bebidas.

Portanto, diante do que foi pesquisado, observa-se que as mudanças que a Anvisa traz, se fazem importantes, uma vez que dá eficácia para o dever de informar do fornecedor e o princípio da transparência, estampados do Código de Defesa do Consumidor. A rotulagem destes alimentos, que passará por uma série de mudanças vem a contribuir para o processo de decisão do consumidor no momento do negócio jurídico. 


\section{REFERÊNCIAS}

ALMEIDA, Joao batista de. A proteção jurídica do consumidor. 3. ed. rev., atual. e ampl. São Paulo: Saraiva, 2002.

BAUDRILLARD, Jean. A sociedade de consumo. 2. ed. Lisboa: Edições 70, 2009.

BEJAMIN, Antonio Herman V.; MARQUES, Claudia Lima; BESSA, Leonardo Roscoe. Manual de direito do consumidor. 6. ed. rev., atual. e ampl. São Paulo: Revista dos Tribunais, 2014.

CAMPBELL, Colin. A ética romântica e o espírito do consumismo moderno. Tradução de Mauro Gama. Rio de Janeiro: Rocco, 2001.

BRASIL. Código de Defesa do Consumidor. Lei n ${ }^{\circ}$ 8.078, de 11 de setembro de 1990. Brasília: Planalto. Disponível em: < http://www.planalto.gov.br/CCIVIL_03/leis/L8078.htm>. Acesso em: 27 jul. 2015.

CRAVEIRO, Célia; CUNHA, Sílvia. Publicidade e alimentação: mistura explosiva? Revista eletrônica Nutrícias N. ${ }^{7} 7$. Associação Portuguesa dos Nutricionistas, 2007. Disponível em: <http://www.itau.pt/pdfs/alimentacao/pub-alimentacao-2007.pdf>. Acesso em: 25 jul. 2015.

EFING, Antônio Carlos; SOUZA, Maristela Denise Marques de. O comportamento do consumidor sob influência da publicidade e a garantia constitucional da dignidade humana. Revista de Direitos Fundamentais e Democracia, v. 16, n. 16, p. 70-94. Curitiba: 2014. Disponível em:

$<$ http://revistaeletronicardfd.unibrasil.com.br/index.php/rdfd/article/view/532/400>. Acesso em: 25 jul. 2015.

EFING, Antônio Carlos. Fundamentos do direito das relações de consumo. 3. Ed. Curitiba: Juruá, 2011.

FERREIRA, Heline Sivini. A biossegurança dos organismos transgênicos no direito ambiental brasileiro: uma análise fundamentada na teoria da sociedade de risco. 2008. $368 \mathrm{f}$. Tese de Doutorado em Direito. Universidade Federal de Santa Catarina, UFSC, Florianópolis, 2008. Disponível em:

<https://repositorio.ufsc.br/xmlui/bitstream/handle/123456789/91741/252586.pdf?sequence= 1\&isAllowed=y>. Acesso em: 25 jul. 2015.

GRINOVER, Ada Pellegrini et al. Código brasileiro de defesa do consumidor: comentado pelos autores do anteprojeto. 7.ed. Rio de Janeiro: Forense Universitária, 2001.

GUIMARÃES, Paulo Jorge Scartezzini. A publicidade ilícita e a responsabilidade civil das celebridades que dela participam. São Paulo: Revista dos Tribunais, 2001.

HENRIQUES, Isabella Vieira Machado. Publicidade abusiva dirigida à criança. Curitiba: Juruá, 2008. 
INSTITUTO Brasileiro de Defesa do Consumidor. Alimentos alergênicos: Idec apoia a regulamentação da rotulagem. Disponível em: <http://www.idec.org.br/em-acao/emfoco/alimentos-alergenicos-idec-apoia-a-regulamentaco-da-rotulagem $>$ Acesso em: 25 jul. 2015 .

ISHIMOTO, Emília Y; NACIF, Marcia de Araujo Leite. Propaganda e marketing na informação nutricional. Revista eletrônica Brasil alimentos $-\mathrm{n}^{\circ}$ 11. 2001. Disponível em: <http://www.signuseditora.com.br/ba/pdf/11/11\%20-\%20propaganda.pdf > . Acesso em: 25 jul. 2015.

MARQUES, Claudia Lima; BENJAMIN, Antonio Herman V.; MIRAGEM, Bruno. Comentários ao Código de Defesa do Consumidor. 3. ed. rev., atual. e ampl. São Paulo: Revistas dos tribunais, 2010.

NUNES, Rizzatto. Curso de direito do consumidor. 10. ed. rev e atual. São Paulo: Saraiva, 2015.

OLIVEIRA, Mara Suely; MARAN Silvia. Publicidade e proteção do consumidor no âmbito do Mercosul. 1. ed. $2^{\text {a }}$ tir. Curitiba: Juruá, 2004.

PORTAL Anvisa. Diretoria da Anvisa aprova regulamento sobre rotulagem de alergênicos. Disponível em:

<http://portal.anvisa.gov.br/wps/content/anvisa+portal/anvisa/sala+de+imprensa/menu++noticias+anos/2015/diretoria+da+anvisa+aprova+regulamento+sobre+rotulagem+de+alerge nicos>. Acesso em: 25 jul. 2015.

RODRIGUES, Anderson Cleber; RODRIGUES, Isabel Cristina. Análise do grau de conhecimento do consumidor diante da rotulagem de alimentos: um estudo preliminar. XXII Encontro Nacional de Engenharia de Produção. ENEGEP. Curitiba, 2002. Disponível em: <http://www.abepro.org.br/biblioteca/ENEGEP2002_TR53_0299.pdf>. Acesso em: 25 jul. 2015.

SANT'ANNA, Armando. Propaganda: teoria, técnica e prática. São Paulo: Pioneira Thomson Learning, 2002.

VIEIRA, Adriana Carvalho Pinto. VIEIRA JUNIOR, Pedro Abel. Direitos dos consumidores e produtos transgênicos. Curitiba: Juruá, 2008. 